\title{
Ambiguous se-constructions in Bulgarian and their English correspondences
}

\author{
GALINA PETROVA, IVAN SOKOLOV \\ Катедра „Български език и литература”, Университет „Проф. д-р Асен Златаров” \\ Бул. „Проф. д-р Якимов” 1, BG-8010 Бургас \\ Department of Bulgarian Studies, University "Prof. Dr. Asen Zlatarov", Burgas \\ E-mail: galyapetro@abv.bg, mail.sokolov@gmail.com
}

(Received: 24 March 2018; accepted: 12 June 2018)

\begin{abstract}
The Bulgarian clitic se (Bulg. 'ce') has a polyfunctional character due to its diverse morphological status. On the one hand, se is a reflexive pronoun in the short accusative form, which is the same for all persons, numbers, and genders. On the other, the clitic is used as a particle that can have different functions. This homonymy leads to homonymous se-constructions and ambiguous sentences with different interpretations: reflexive, reciprocal, passive, or optative. The aim of this study is to present the morphological status of the clitic in its various uses and the resulting differences in meaning of the se-constructions. A semantic-syntactic approach is adopted to differentiate between the argument and non-argument use of the clitic. If se takes argument position, the clitic is a reflexive pronoun and functions as part of the sentence. In its non-argument use, se functions as a particle and is either part of the verb lexeme or part of the verb form. In the analysis, the corresponding translations into English are provided.
\end{abstract}

Keywords: Bulgarian, English, reflexive clitic, se-constructions, ambiguity

\section{Introduction}

The ambiguity of the se-constructions in Bulgarian is a result of the different morphological status of the reflexive clitic se (Bulg. 'ce') used in verb-adjacent position: it can be a personal pronoun or a particle with different functions. When the clitic is a reflexive pronoun, it functions as part of the sentence and takes object position. When it is a particle, it is part of the analytical verb lexeme or part of the verb form. This homonymy poses difficulties in the interpretation of sentences with the same surface structure when there is limited context. The aim of this study is to present the diverse morphological status of the clitic in homonymous se-constructions and the resulting difference in their interpretations: reflexive, reciprocal, passive, optative, etc. and their possible equivalents when translated into English.

\section{The morphological status of the clitic se: distinction criteria}

The question of the character of se-constructions, and hence the morphological status of the clitic se, is not new in linguistics, but it has not found a unanimously accepted answer yet. This is due to the fact that the combinations between verbs and se are rather diverse semantically and, besides, they often have homonymous 
relations with each other. They can express passive and optative meaning as well as reflexive and reciprocal meaning (only with part of the medial se-verbs). This semantic spectrum brings about the intersection of a wide range of questions theoretically related to the issue of voice and its expression in Bulgarian, the means for expression of reflexivity and reciprocity (lexical or grammatical) and, as a consequence, the role of the clitic in these different uses (see Penchev 1995, 1996, 1998, Koeva 1995, 1998, 2004, 2006, 2007, 2008, Petrova 2008, Dimitrova 2009, Nitsolova 2011, Ivanova-Petrova 2017).

There is no doubt that the clitic se functions mainly as a particle (word-building or word-forming), i.e. as a desemanticized element. In these use, se is either part of the verb lexeme or part of the verb form. Still debatable in linguistics is the question whether and when it is a reflexive pronoun, i.e. an autosemantic unit in cases such as Тя се мие 'She is washing (herself)', Тя се питаше къде е сгрешила 'She was asking herself what she did wrong'. Some authors think that мия се, nuтам се, etc. are verb lexemes with reflexive semantics. This view is shared by L. Andreychin, I. Kutsarov, and R. Nitsolova (ANDREYCHIN 1978: 135, KuTSAROV 1997: 63, Nitsolova 2008: 160, 241-242). According to other linguists, these are verb forms expressing "the reflexive version of the active voice" (STOJANOv 1983: 242-245). For a third group of researchers, these are syntactic structures where the transitive verbs мия 'wash', питам 'ask' take a pronoun as an object, i.e. se is a reflexive pronoun (Penchev 1995: 404-405, Pashov 1999: 128, Koeva 2004: 192-194, Petrova 2008: 25-26). According to the latter view, in such uses the reflexive se denotes a referential identity between the elements in subject and object positions (as opposed to the lack of such referential identity in the use of nonreflexive pronouns in the same position, for example, Тя го мие 'She is washing him', Тя го питаше къде е сгрешила 'She was asking him what she did wrong'). In both cases, however, the short pronominal forms take the internal argument position in the respective predicate structure. The verb мия 'wash' is transitive and opens two argument positions, internal and external, for its clarifying elements: мия (някой, някого/нещо), 'wash' (sb мия sb/sth). The same is true for the other verb, too: питам (някой, някого), 'ask' (sb питам sb). When the referents of the internal and external arguments are the same, the object position is taken by a reflexive-pronoun себе cu (sebe si, full form) or ce (se, short form). It is important that in its function as a reflexive pronoun the short form can be substituted by the full form under certain conditions, i.e. се= себе си: е.g. Тя питаше себе си къде е сгрешила, а не тебе 'She was asking herself, not you, what she did wrong'. This alternative use is distinctive of the pronominal status of the clitic and differs from its use as a particle, i.e. in non-argument position, where $c e \neq$ себе $c$.

Not all transitive verbs take a reflexive object, however. The necessary condition for the appearance of se is the meaning of the verb: it has to allow the action to be directed to the object. For example, the verb изпрамам 'see off' is transitive, but its meaning 'accompany somebody to a place of departure' (BTR 2008) excludes the option that the agent and the patient are the same person (cf. $A$ з ще те изпратя 'I will see you off' and *Аз ще се изпратя 'I will see myself off'). 
There are, however, uses where both the reflexive and the non-reflexive clitic (for example, моля го, моля се) can appear in contact position with the verb but only one of them is in argument position. The go clitic (Bulg. 'го') in Молих го да ми прости 'I prayed to/asked him to forgive me' is a personal pronoun. It takes the argument position in the structure of the transitive verb моля (някой, някого, за нещо), 'pray/ask' (sb моля sb for sth / to do sth), and acts as a direct object in syntax. The meaning of the verb is 'urge or persuade somebody with words to do something I want' (BTR 2008). Ноwever, моля се 'pray/ask' in Моля се да ми простиш 'I pray that you forgive me' does not mean 'pray to myself' but 'address somebody with a request' (BTR 2008). The difference in meaning shows that there is a different verb lexeme with a different argument structure: моля се (някой, на някого, за нещо), pray/ask (sb моля се to sb for sth/to do sth). Here the se clitic is not in argument position but is part of an intransitive verb, i.e. a particle with word-building function. The same can be seen in other verbs expressing some kind of emotion as, for example, изплашвам 'scare' - изплашвам се 'get scared', тревожа 'disturb/worry' - тревожа се 'worry', изненадвам 'surprise' изненадвам се 'get surprised', ядосвам 'make angry' - ядосвам се 'be angry', безпокоя 'disturb' - безпокоя се 'worry', изнервям 'make nervous' - изнервям ce 'be nervous', etc. Изплашвам 'scare' is a causative verb defined as 'become the reason for somebody to experience fear' (BTR 2008). The causer is in the position of an external argument and the argument in object position acts as a patient, because it undergoes a change of its emotional state, as has been shown in PADUCHEVA 1996. Изилашвам се 'get scared' is a one-place intransitive verb defined as 'become afraid, taken with fear' (BTR 2008), i.e. in изплашвам се (някой), 'get scared' (sb изплашвам се) the argument is in subject position acting as an experiencer. By adding se, the verb turns from causative to non-causative, i.e. there is decausativation where the lexical meaning changes. The role for this lexical transformation is taken by the clitic se.

There are also uses in verb-contact position where se can be either in argu-

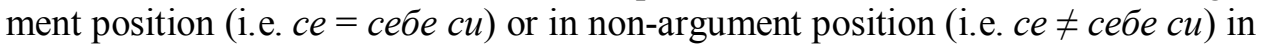
the role of a word-building particle, for example, Оглеждам се (= себе си) в огледалото 'I am looking at myself in the mirror' and Оглеждам се ( $\neq$ себе си) наоколо 'I am looking around'. In the first case оглеждам се is a syntactic construction with reflexive meaning, while in the second it is a medial se-verb with non-reflexive meaning.

Besides by syntactic, reflexivity can be expressed by lexical means as well. However, in the latter case, the direction of the action to the subject is implicated in the meaning of the verb, for example, Свидетели твърдят, че мъжът се е самозапалил 'Witnesses claim that the man set himself on fire'. The verb самозапалвам се means 'set one's own self on fire' (BTR 2008). It is a one-place intransitive verb, i.e. самозапалвам се (sb самозапалвам се) and se is part of the verb lexeme, i.e. it is in non-argument position.

Some se-constructions with a reflexive object can be interpreted in two ways. For example, Те се питаха къде са сгрешили can mean that everybody asked 
oneself: 'They asked themselves what they did wrong' or that they asked each other: 'They asked each other what they did wrong'. The reflexive interpretation suggests that each of the participants directs the action to himself or herself: he asks himself $(\mathrm{A} \rightarrow \mathrm{A})$ and she asks herself $(\mathrm{B} \rightarrow \mathrm{B})$. The reciprocal interpretation suggests that the participants exchange their roles, i.e. each of them is both a subject and an object of the action: he asks her $(\mathrm{A} \rightarrow \mathrm{B})$ and she asks him $(\mathrm{B} \rightarrow \mathrm{A})$, or (A $\leftrightarrows \mathrm{B}$ ), as has already been shown (Petrova 2008: 79-84). This reciprocal transitivity is marked by the clitic se but the necessary condition is that the verb is in a plural form. When it is in the singular, the reading is only reflexive.

There is reciprocity, although lexical, in verbs such as състезавам се 'compete', обзалагам се 'bet', дуелирам се 'duel', споразумявам се 'reach agreement', etc. What is common in their meaning is that they denote a two-way direction, a symmetry of the action, i.e. the attribute of 'reciprocity' is implicated in their meaning. We can take as an example the verb споразумявам се meaning 'come to mutual agreement'. In such uses, se is a word-formation particle. These verbs are known as 'reciproca tantum' and are studied in detail in linguistic literature (see Koeva 1995, Koeva 2004, Penchev 1996). Since they are verb lexemes, reciprocity is expressed both by the singular and plural forms, for example, $c b c$ тезавам се (Sg.) and състезаваме се (P1.). There are also verbs with defective paradigm, which are used only in the plural: споглеждаме се 'we throw glances at each other', спобутваме се 'we nudge each other'. This limitation is lexically defined: the meaning of these verbs includes the semantic component 'each other', which presupposes two partner sides in subject position.

Reciprocity is also present in the sentence Момичетата се търсят от сутринта 'The girls have been looking for each other (one another) all morning', i.e. each one is looking for the other(s) (here, the verb търся 'look for' excludes reflexivity). However, the sentence can have another interpretation: the girls have been looked for, somebody else has been looking for them. In the latter reading, the sentence is the result of the passive transformation of the initial Родителите [например] търсят момичетата от сутринта 'The parents [for example] have been looking for their girls all morning'. The situation denoted by the active and the passive voice is the same but in the passive, the focus shifts to the object of the action. The role of the clitic is to indicate that the agent voids the subject position, which is taken by the element in object position. The relation between търсят and търсят се is not lexical but grammatical (diathetic). This means that the verb has only changed its form and this is made explicit by the se particle. In this use, it has a word-forming function.

As a particle, se also functions in optative constructions and it is an obligatory element together with the dative clitic as an indirect object. The dative pronoun denotes the subject of the wished action: Спи ми се 'I feel like sleeping', Не ми се яде (т. е. не сьм гладен) 'I don't feel like eating, i.e. I'm not hungry', Пие ми ce кaфpe 'I feel like some coffee', etc. Such constructions are specific for the fact that they present a person's wish as determined by a physiological need or subjective preference. In contrast with them, in the sentence Аз искам да спя 'I want to 
sleep', the wish is presented as an expression of will or the subject's intention. In the second construction, the argument in the role of experiencer (the wisher) takes subject position and the construction is marked with the feature [+intentionality]. To explicate the feature [-intentionality], the experiencer is "demoted" and takes object position. This change in the meaning of the construction is also signalled by the appearance of the particle se: аз искам да... $\rightarrow$ иска ми се да... (PETROVA 2006: 135-141). A clear illustration of the difference between the two types of wishes are the sentences Искам да спя, но не ми се спи 'I want to sleep but I don't feel like sleeping' and Не искам да пуша, но ми се пуши 'I don't want to smoke but I feel like smoking'.

From the above analysis it can be concluded that the reliable criterion for the morphological status of the clitic se in se-constructions is its argument or nonargument use. $S e$ is a reflexive pronoun when it marks coreference between the arguments in subject and object position. In such use the clitic is a sentence part. In non-argument use it is either part of the verb lexeme or part of the verb form and functions as a particle. This distinction is particularly important for the interpretation of ambiguous sentences.

\section{Interpretation of sentences with homonymous se-constructions}

Homonymous $s e$-constructions can have the following meanings: reflexive, reciprocal, passive, and optative. Some of the se-constructions oppose each other with regard to these meanings, for instance, reflexivity - reciprocity, reflexivity - passivity, passivity - optativity, etc. Another part of the se-constructions are homonymous with medial se-verbs that do not have these meanings, for instance $s e$-verb and $s e$-construction with reflexive meaning or $s e$-verb and passive construction.

\subsection{Se-constructions with reflexive and reciprocal meaning}

(1) Ана и Борис се обвиняват за случилото се.

Sentence (1) can be interpreted in two ways: each of the two blames himself or herself (1a) or the two blame each other (1b):

(1a) Anna and Boris blame themselves for what happened.

(1b) Anna and Boris blame each other for what happened.

The verb обвинявам 'blame' is two-place transitive and opens a position for an external argument that takes direct object position: обвинявам (някой, някого), 'accuse' ( $\mathrm{sb}$ обвинявам sb). Its meaning allows to direct the action to somebody else or to oneself. For this reason, both a reflexive and a reciprocal reading of the sentence are possible (but only with plural subjects). When there is coreference between the subject and the object, the object position is taken by the reflexive pronoun se (се = себе си), as in (1a). In the reciprocal interpretation (1b), each person blames the other one, i.e. there is mutual transitivity (A $\leftrightarrows \mathrm{B})$. Here is why we 
think that the polypredicative structure (1c), where in two simple sentences the participants exchange their roles of subject and object, is basic for sentence (1):

(1c) Ана обвинява Борис $(\mathrm{A} \rightarrow \mathrm{B})$ и Борис обвинява Ана $(\mathrm{B} \rightarrow \mathrm{A})$. 'Anna blames Boris $(\mathrm{A} \rightarrow \mathrm{B})$ and Boris blames Anna $(\mathrm{B} \rightarrow \mathrm{A})$ '.

To neutralize the reflexive-reciprocal polysemy, the Bulgarian language uses the facultative phrases един друг 'each other /one another' or взаимно 'mutually', for example, Ана и Борис се обвиняват един друг за случилото се.

\subsection{Se-constructions with reflexive, reciprocal and passive meanings}

(2) Учителят трябва да се уважава.

Sentence (2) has two possible interpretations:

(2a) A teacher has to respect himself.

(2b) A teacher has to be respected.

The first interpretation (2a) is reflexive and is related to the need for self-respect. The referential identity of the arguments in subject and object positions is explicated through the use of the reflexive pronoun $s e(c e=$ себе си).

The second interpretation ( $2 \mathrm{~b})$ is related to the need for the teacher to be respected by somebody (parents, society, etc.). It is a passive construction resulting from the following transformation: Active: Родителите трябва да уважават учителя 'Parents have to respect a teacher' $\rightarrow$ Passive: Учителят трябва да се уважава от родителите 'A teacher has to be respected by parents' $\rightarrow$ Учителят трябва да се уважава (от родителите) 'A teacher has to be respected (by parents)'. In the last sentence, there is a reduction in the syntax of the argument acting as agent, resulting in the identicalness of the surface structures (2) of the two different meanings. In the second use, the clitic se is part of the passive verb form.

The meaning of the verb уважавам 'respect' also allows reciprocal reading when the subject is in the plural, hence sentence (3) may have three interpretations: reflexive (3a), reciprocal (3b), and passive (3c):

(3) Учителите трябва да се уважават.

(3a) Teachers have to respect themselves.

(3b) Teachers have to respect one another.

(3c) Teachers have to be respected.

There are also cases such as (4) where the meaning of the verb allows reflexive (4a) and passive interpretations (4b), but excludes the reciprocal one, although the subject is a plural noun:

(4) Тези жени се продават за много пари.

(4a) These women sell themselves for a lot of money.

(4b) These women are sold for a lot of money. 
This is one of the rare cases when the ambiguity can be preserved in English, if necessary: These women sell for a lot of money. As an intransitive verb, 'sell' can mean 'exchange for money', i.e. somebody sells the women for a lot of money, or 'be offered at the price mentioned', i.e. somebody offers them or the women offer themselves for a lot of money (OALD 2015).

There are also sentences $(5,6)$ where the meaning of the verb excludes a reflexive but allows reciprocal ( $5 \mathrm{a}$ and $6 \mathrm{a}$ ) and passive ( $5 \mathrm{~b}$ and $6 \mathrm{~b}$ ) interpretations:

(5) Момичетата се търсят от сутринта.

(5a) The girls have been looking for each other all morning.

(5b) The girls have been looked for all morning.

(6) Седяха така в залата, че не се виждаха.

(6a) They were sitting in the room so that they could not see each other.

(6b) They were sitting in the room so that they could not be seen.

A condition for the unambiguous interpretation of the above examples (2-6) is the presence of the semantic feature [+ person] of the element in subject position. If the feature is [-person], the interpretation is only passive (7):

(7a) Трудът на учителя трябва да се уважава.

'The teacher's job has to be respected'.

(7b) Тези антики се продават за много пари. 'These antiques sell/are sold for a lot of money'.

(7c) Откраднатите коли се търсят от сутринта. 'The stolen cars have been looked for all morning'.

(7d) Имаше много хора и двете малки картини не се виждаха. 'There were a lot of people and the two small paintings could not be seen'.

\subsection{Se-constructions with reflexive meaning and se-verbs}

(8) Жената се е отровила.

Sentence (8) is ambiguous because it is not clear whether the woman took the poison intentionally (8a) or the poisoning happened by chance, unintentionally $(8 b)$ :

(8a) The woman poisoned herself.

(8b) The woman got poisoned.

The first interpretation supposes the presence of the verb отравям 'poison' with its meaning 'kill by poison' (BTR 2008) in the basic structure. The verb is causative transitive and opens two argument positions: отравям (някой, някого), 'poison' (sb отравям $\mathrm{sb}$ ). When intentionally directing the action to oneself, the referential identity between the arguments in subject and object positions is explicated by means of the reflexive pronoun $s e(c e=$ себе си). In the second interpretation the action is unintentional, i.e. the subject did not cause her own death. This 
is denoted by the verb отравям се 'become poisoned' meaning 'die from poison' (BTR 2008). The verb is one-place intransitive (sb отравям се) and se is a wordbuilding particle.

\subsection{Se-constructions with reciprocal and passive meanings and $s e$-verbs}

(9) Мария и Ана не се виждат.

Sentence (9) allows for three interpretations:

(9a) Maria and Anna cannot see each other.

(9b) Maria and Anna cannot be seen.

(9c) Maria and Anna do not see each other.

The first interpretation (9a) is reciprocal, i.e. Мария не вижда Ана и Ана не вижда Мария 'Maria does not see Anna and Anna does not see Maria'. The second (9b) is passive, i.e. nobody can see Maria or Anna. In both cases, виждам is a verb of perception meaning 'perceive with eyes' (BTR 2008). The verb is twoplace transitive and opens two argument positions (sb виждам sb/sth). The third interpretation is not related to visual perception, i.e. with the verb виждам, but with the medial verb виждам се meaning 'meet, spend time with somebody after previous arrangement' (BTR 2008). In English, the verb 'see' has the same transitive meanings: 'to become aware of sb/sth by using your eyes' and 'to spend time with sb' (OALD 2015) and the ambiguity between (9a) and (9c) can be preserved. To avoid it, however, the verb of perception is often used with the modal 'can' for physical ability. Besides, 'see' is not used in the progressive aspect with the first meaning, while it is often used in progressive tenses with the second.

\subsection{Se-constructions with passive meaning and se-verbs}

(10) Паииентът не трябва да се безпокои.

Sentence (10) can be interpreted in two ways:

(10a) The patient must not be disturbed.

(10b) The patient must not worry.

In the first interpretation (10a), nobody must disturb the patient or worry him, where безпокои се is the passive form of the causative verb безпокоя meaning 'spoil somebody's peace and quiet, make somebody feel anxious, worried or troubled' (BTR 2008). The verb is two-place transitive (sb безпокоя sb) and se is part of the passive verb form. In the second interpretation (10b), there is the medial verb of emotion безпокоя се meaning 'feel anxious, worried or troubled' (BTR 2008). The verb is intransitive and adds only one external argument with the semantic role of experiencer: безпокоя се (някой), 'worry' (sb безпокоя ce). The clitic se is part of the verb lexeme. 
The same opposition is present in sentence (11):

(11) Солта се разтваря във вода.

The interpretation depends on whether the action is intentional, i.e. whether somebody dissolves the salt (11a), or whether the sentence is about the solubility property of salt in water $(11 \mathrm{~b})$ :

(11a) Salt is dissolved in water.

(11b) Salt dissolves in water.

In the first interpretation (11a), the se-construction has a passive meaning and the clitic is part of the passive form of the causative transitive verb разтварям meaning 'make a given substance become absorbed in another' (BTR 2008). In the second interpretation (11b), there is the medial verb разтварям се meaning 'become absorbed in a liquid so that a homogeneous mixture is formed' (BTR 2008) and the clitic is part of a verb lexeme.

\subsection{Se-constructions with passive and optative meanings}

(12) Нищо не ми се обяснява.

Sentence (12) is ambiguous:

(12a) Nothing is (being) explained to me.

(12b) I don't feel like explaining anything.

There are different generation mechanisms involved in the identical surface structure of sentence (12). On the one hand, this is a passive diathesis with the meaning 'nobody explains anything to me' as a basic structure (12a). On the other, it is an optative diathesis, where the basic structure is polypredicative: $\mathrm{He} \mathrm{мu} \mathrm{ce}$ иска да обяснявам, i.e. 'I have no desire, I do not wish to explain' (12b). Therefore, the role of the dative clitics is different: addressee in the passive interpretation and experiencer in the optative. In the passive structure, the clitic se is part of the passive form of the verb обяснявам 'explain'. In such constructions which are the result of optative diathesis, se is a particle which indicates a change in the syntactic position of the experiencer argument from subject to object position: $a_{3}$ не искам $\rightarrow$ не ми се иска.

\subsection{Passive se-constructions with actual and non-actual (habitual and modal) meaning}

(13) Тук не се пуши.

Sentence (13) can be interpreted in several ways depending on the context of the situation but all versions have a passive meaning, i.e. $s e$ is a particle with formbuilding function. The ambiguity of the sentence stems from the two varieties of 
the passive: actual and non-actual. The non-actual meaning also has two versions: habitual and modal. The actual passive denotes situations which are localized in time, while the non-actual is used for situations that are not related to a certain moment in time. The habitual passive denotes a common, regulated, or routine state, as shown in LetUCHII 2014. The modal passive denotes hypothetical situations related to necessity, prohibition/permission, ability/disability to perform a certain action. Often, the doer is not mentioned in the non-actual passive because it can be conceptualized as general or non-defined: всеки 'everybody', който $и$ да е 'whoever', никой 'nobody', някой 'somebody'.

Sentence (13) includes the verb пуша 'smoke'. It is two-place transitive (sb nyma sth). The external argument with the role of agent is not given but neither is the internal one (cigarettes) because it is implied. As a result, the passive construction is impersonal (Koeva 2004: 212-214, Penchev 1995: 412-414).

Example (13) illustrates all three meanings of the passive. The actual interpretation (13a) of the basic structure in the active voice suggests that nobody is smoking in this place at the moment:

(13а) Тук в момента никой не пуши.

'Nobody is smoking here now', 'It is not being smoked here'.

The habitual interpretation (13b) suggests that in this place (in this house, for example) nobody smokes, nobody has ever smoked and this is the usual situation or practice (this is generally a non-smoking place):

(13b) Тук никой не пуши, никога не се е пушило.

'Nobody smokes here, nobody has ever smoked', 'It is not smoked here'.

As can be seen, the difference between the actual and the habitual interpretation can easily be expressed using the progressive and the non-progressive aspect in English.

The modal interpretation (13c) is related to the ban for smoking. Therefore, the basic active construction includes a modal verb, which is not expressed in the surface structure: Active: Тук никой не трябва да пуши $\rightarrow$ Passive: Тук не трябва да се пуши $\rightarrow$ Тук не се пуши (see PетRоva 2008: 109-112):

(13c) Тук никой не трябва да пуши, забранено е.

'Nobody must smoke here, smoking is forbidden', 'No smoking'.

With other verbs, the range of meanings is smaller or has other modal nuances, for example:

(14) Тук не се спи.

(14a) В момента тук никой не спи.

'Nobody is sleeping here now', 'It is not being slept here'.

(14b) Тук [например на гарата] не може да се спи, не е разрешено.

'You cannot sleep here [at the train station, for example], it is not allowed'. 
(14c) Тук [например в този хотел] не може да се спи, не е възможно [защото например е много шумно].

'You cannot sleep here [in this hotel, for example], it is impossible [because it is too noisy, for example]'.

\section{Conclusion}

The presented cases of syntactic ambiguity result from the polyfunctional clitic se, which is specific for the Bulgarian language, and from the homonymy between the se-constructions. The applied semantic-syntactic approach determining the argument or non-argument use of the clitic in all homonymous se-constructions is a reliable criterion for the interpretation and translation of equivocal sentences. This approach allows for explanation of the differences in meaning of ambiguous sentences in different processes of syntactic derivation. The results of the present study can be applied in the fields of comparative linguistic research, foreign language teaching, and translation practices.

\section{References}

ANDREYCHIN 1978 = АндРейчин Л. Основна българска граматика. София: Наука и изкуство, 1978.

BTR 2008 = АндРейчин Л. и др. Български тълковен речник. София: Наука и изкустBo, 2008.

Dimitrova $2009=$ ДимитровА М. Залог и диатеза: функциониране на залогови форми в текст. В кн.: СтАнков В. (съст.) Българско езикознание. Т. 5. Проблеми на граматичната система на българския език - глагол. София: Академично издателство „Проф. М. Дринов”, 2009. 278-303.

IVANOVA-PETROVA 2017 = ИвановA Е. Ю., ПетРовА Г. М. Болгарские возвратные клитики се и си: омонимия, полисемия, синтаксис. Вопросы языкознания 2017/1: 74104.

Koeva 1995 = Коева С. Семантична и синтактична интерпретация на реципрочните изречения. Български език 1995/1-2: 160-163.

Koeva 1998 = Koeva S. Reflexive, passive, optative, reciprocal and impersonal verbs in Bulgarian. Научни трудове на Пловдивския университет. Филология. Т. 35. Kn. 1. Пловдив, 1998. 142-157.

Koeva 2004 = КоеВА С. Семантично и синтактично описание на диатезите в българския език. В кн.: Пенчев Й. и др. Българско езикознание. Т. 4. Когнитивна граматика на българския и френския език - описание и формализация. София: Издателство на БАН, 2004. 182-231.

Koeva $2006=$ КоевA C. Синтактични редувания в български - диатези и алтернации. Български език 2006/4: 19-32.

Koeva 2007 = Koeva S. Bulgarian alternations - lexicon or grammar? Southern Journal of Linguistics 29 (2007): 77-106.

Koeva 2008 = Koeva S. Semantic nature of diatheses. Studia Kognitywne / Études cognitives 8 (2008): 71-95.

KUTSAROV 1997 = КУцАРОв И. Лекции по българска морфология. Пловдив: Университетско издателство „Паисий Хилендарски”, 1997. 
LETUCHII 2014 = ЛЕтучий А. Б. Между пассивом и декаузативом: русские модальные пассивы. Acta Linguistica Petrolitana 2014/3: 365-395.

Nitsolova 2008 = НицоловА Р. Българска граматика. Морфология. София: Университетско издателство „Св. Климент Охридски”, 2008.

Nitsolova 2011 = НицоловА Р. Една нова концепция за залога на глагола в българския език. В кн.: БояджиЕв Т., ПоПОвА В., АЛЕКСИЕвА К. (съст.) Научни трудове в памет на Георги Герджиков. София: Университетско издателство „Св. Климент Охридски", 2011. 207-222.

OALD $2015=$ Oxford Advanced Learner's Dictionary. 9th edition. Oxford: Oxford University Press, 2015.

PaducheVA 1996 = Падучева Е. В. Семантические исследования. Семантика времени и вида в русском языке. Семантика нарратива. Москва: «Языки славянской культуры», 1996.

PASHOV 1999 = ПАшов П. Българска граматика. София: Хермес, 1999.

PENCHEV 1995 = Пенчев Й. Функции на форманта $c e / c u$ в съвременния български език. Български език 1995/5-6: 404-418.

PencheV 1996 = Пенчев Й. Реципрочни конструкции в българския език. Списание на БАН. Кн. 4. София, 1996. 30-35.

PenCHeV 1998 = Пенчев Й. Синтаксис на съвременния български книжовен език. Пловдив: Неделник, 1998.

Petrova 2006 = ПетРова Г. Семантични роли на кратките дателни местоимения. Бургас: Димант, 2006.

PEtrova $2008=$ ПетРОВА Г. Функизии на клитиките се $и$ си в съвременния български език. Бургас: Димант, 2008.

StOJANOV 1983 = Стоянов С. (ред.) Граматика на съвременния български книжовен език. Т. 2. Морфология. София: Издателство на БАН, 1983. 